\title{
Modeling on Metabolic Rate and Thermoregulation in Three Layered Human Skin during Carpentering, Swimming and Marathon
}

\author{
Dev Chandra Shrestha*, Saraswati Acharya, Dil Bahadur Gurung \\ Department of Mathematics, School of Science, Kathmandu University, Dhulikhel, Nepal \\ Email: *shresthadev28@yahoo.com
}

How to cite this paper: Shrestha, D.C., Acharya, S. and Gurung, D.B. (2020) Modeling on Metabolic Rate and Thermoregulation in Three Layered Human Skin during Carpentering, Swimming and Marathon. Applied Mathematics, 11, 753-770. https://doi.org/10.4236/am.2020.118050

Received: June 13, 2020

Accepted: August 18, 2020

Published: August 21, 2020

Copyright ( 2020 by author(s) and Scientific Research Publishing Inc. This work is licensed under the Creative Commons Attribution International License (CC BY 4.0).

http://creativecommons.org/licenses/by/4.0/

\begin{abstract}
Metabolisms play a vital role in thermoregulation in the human body. The metabolic rate varies with the activity levels and has different behaviors in nature depending on the physical activities of the person. During the activity, metabolic rate increases rapidly at the beginning and then increases slowly to become almost constant after a certain time. So, its behavior is as logistics in nature. The high metabolic rate during activity causes the increase of body core temperature up to $39^{\circ} \mathrm{C}$ [1] [2]. The logistic model of metabolic rate is used to re-model Pennes' bioheat equation for the study of temperature distribution in three layered human dermal parts during carpentering, swimming and marathon. The finite element method is used to obtain the solution of the model equation. The results demonstrate that there is a significant change in tissue temperature due to sweating and ambient temperature variations.
\end{abstract}

\section{Keywords}

Pennes' Bio-Heat Equation, Metabolic Rate, Finite Element Method, Physical Activities, Thermoregulation

\section{Introduction}

\subsection{Thermoregulation}

Thermoregulation is the process of transporting thermal energy through the biochemical process in the human body. It maintains its required internal temperature. It keeps the body temperature in the equilibrium position. This process is applicable for diagnostic and therapeutic applications and involves either mass 
or heat transfer. In the human body, the heat transfer is affected by blood vessel geometry, local blood flow rates, the thermal capacity of blood and produces metabolic energy. The Body regulates its temperature through internal metabolic processes and internally maintains a narrow range of internal temperature. Heat is usually generated by the metabolic process but under the condition of excessive cold, the body generates heat by shivering. Heat is lost and gained through the process of convection, radiation, blood perfusion and conduction, while evaporation contributes only heat loss from the body to the environment. Total heat loss from body surface depends on the temperature difference between skin and environment.

Hypothalamus is the main part of the brain that controls thermo-regulation. When it senses the internal temperature becoming too low or too high, it sends signals to different organs such as muscles, glands, and nervous. The body mechanism responds and helps to maintain the temperature to normal position. Different people have different thermal behaviors even in the same environment.

The biochemical processes have been divided into three broad categories: hypothermia, hyperthermia and cryobiology. Hypothermia is the phenomena in which the body core temperature falls to $35^{\circ} \mathrm{C}$ or below it. This phenomenon can potentially lead to cardiac arrest, brain damage, or even death. In Hyperthermia, body core temperature rises to $42^{\circ} \mathrm{C}$ or above it. Due to this phenomenon, it can suffer brain damage or even death, where cryobiology is the blood subfreezing temperature period. The average healthy person has a normal body core temperature between $36.1^{\circ} \mathrm{C}$ to $37.8^{\circ} \mathrm{C}$ [3]. But temperature rising up to $39.5^{\circ} \mathrm{C}$ during the high intensity exercises doing on long period [1] [2]. However, if the body temperature is extreme, it can affect the body's ability to work. Thermo-regulation phenomena are affected by either environment or biological factors such as metabolic rate, dehydration, gender, etc. The internal temperature of the body rises due to fever, physical exercise and digestion of the food. Besides the internal temperature decreases due to use of alcohol, drug and some functioning of thyroid glands, etc. [4].

\subsection{Circulatory System}

The circulatory system also plays a vital role to maintain body temperature. The vasodilation and vasoconstriction are the two main processes which maintain heat and balanced the temperature of the body. If the body has a high temperature, the body controls the temperature and keeps in normal by occurring the mechanism of vasodilation and sweating. The blood flow rate to the skin increases by expanding the wider blood vessels under skin and heat energy dissipated by the radiation process. On the other hand, sweat glands lying under the skin surface release sweat in the form of water and vapour from the skin surface and maintain the body temperature is normal. If the body has a low temperature, it maintains the body temperature by the mechanism of vasoconstriction and thermo-genesis. The blood flow rate to the skin reduces by contracting the peripheral blood vessels lying under the skin surface and conserving heat 
energy near the warm inner body and keeps the body temperature normal. Besides body muscles, organs, glands and hormones also produce heat by their mechanism.

Figure 1 represents the thermoregulation system in the human body. It shows that if the body has a low temperature, it maintains by the process of vasoconstriction and thermogenesis and if body temperature is high, it controls by the process of vasodilation and sweating to keeps the body temperature is normal.

\subsection{Metabolism}

The metabolic rate of a person increases due to increases in the kinetic energy and helps on increasing the temperature of the body. Some of the hormones and thyroid gland releases hormones to increase metabolism. This increased metabolism creates energy in the form of heat and maintains body temperature as normal. Basal metabolism is the minimum amount of energy release in the body to sustain life in the rest position. Body uses this energy for the circulation of blood, respiration and functioning of cells and different organs. The active person has a more metabolic rate than a less active person [5]. In general, the metabolic rate is proportional to the body weight and depends upon the type of exercises, body surface area, health, mental state, sex, thermal conductivity, age and atmospheric conditions, etc. Due to the hormones, the metabolic rate is highly increased in fever [6]. The metabolic heat produced by the exercising muscles is transported by the circulating blood to the surface of the body and released to the environment either by radiation and convection or by evaporation of sweet appears in a hot environment. According to the conservation law of energy in a healthy body, the amount of heat gain is equal to the amount of heat loss, and is given by [7]

$$
M=W \pm R \pm C+E+H
$$

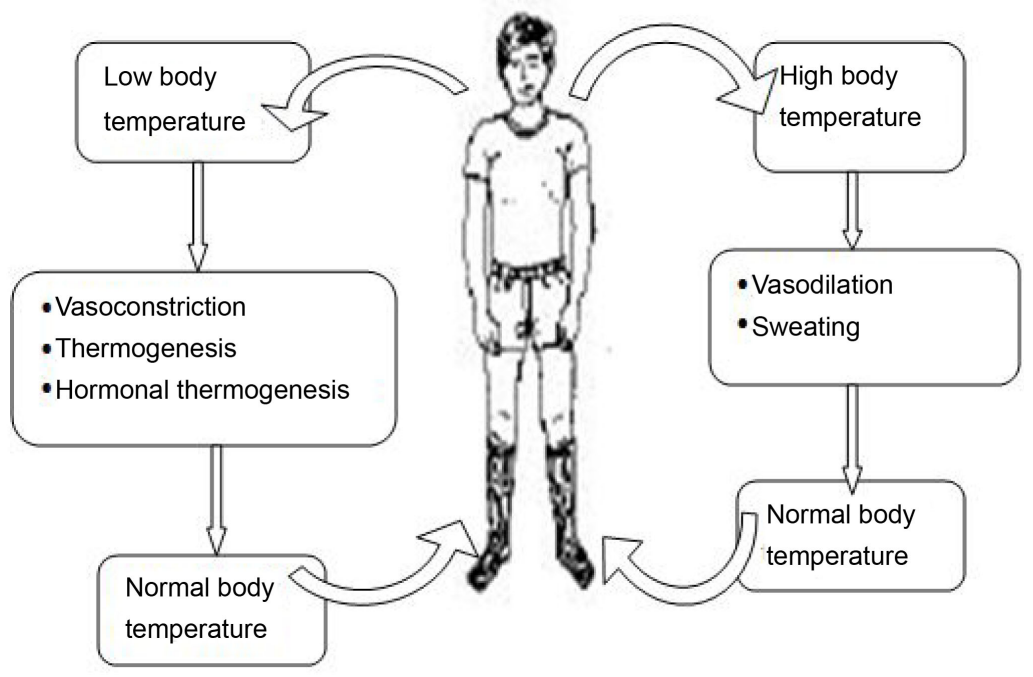

Figure 1. Schematic diagram of thermoregulation system in human body. 
when the body is at rest, there is normal blood flow and metabolic activity however, during exercise there is abnormal blood flow and metabolic activity. When a person engaged in different types of physical activities, the body requires additional fuel which increases the metabolic rate and the rate of heat production [8]. The body must use its mechanism to remove the additional heat produced to keep the internal temperature at a healthy level. The body always produces heat, so the metabolic heat $(M)$ is always positive, varying with the activity level. When environment temperature is lower than the body temperature, a thermal gradient is created which favors heat loss from the body core to the environment. That heat energy is transformed into the skin by convective blood flow and emitted by radiation, convection and sweat evaporation. The driving force of radiation and convective heat loss depends on the maintains of a large temperature gradient between the environment and body. When the environment temperature exceeds than body temperature, the gradient for heat exchange is reversed and the body gains the heat.

Different people have different thermal behavior even in the same environment. However, as environment temperature rises, sweat rate also increases. In a resting lightly clad man, the sweet begins at $29^{\circ} \mathrm{C}$ environment while in the resting nude man sweating begins at the environment temperature at $31^{\circ} \mathrm{C}$ [9]. Sweat evaporation becomes the primary means of heat dissipation when convective and radiative heat exchange is minimal. In a hot moist environment, a healthy man approximately $1.94 \mathrm{ml}$ sweat losses from the body [10]. Being lost of heat through evaporation even an entirely high metabolic rate can also be limited by the body mechanism. If the combined heat loss from the body is less than the metabolic heat rate production of the body, the excess heat must be store in the body, but storage heat energy $(H)$ is always small because the body has a limited thermal storage capacity. This storage heat energy helps on bring the body temperature rise and when the metabolic heat is less than combine heat loss, the body temperature falls.

During the mild exercises, the muscles are the main source of metabolic heat, and during intense exercise, it may occur up to $90 \%$ [11]. In heavy exercises, the respiration process plays the role of increasing metabolism. In low-intensity exercises as sitting, typing, cooking, etc there is very little difference in the vascular system so the metabolic rate is similar to the basal metabolic rate. While in high-intensity exercises, as marathon, wrestling, etc most of the organs come in movement with high kinetic energy so, there is a loss of energy. In moderate-intensity exercise as carpentering, driving, etc. helps on decreasing body weight by increasing cardiovascular exercise.

From the experimental data, the average basal metabolic rate $(B M R)$ of (30 60) years old healthy man, of body weight $74 \mathrm{~kg}$ has $1737 \mathrm{kcal} /$ day [12]. This shows that the $B M R$ of the healthy human body has $1114 \mathrm{w} / \mathrm{m}^{3}$, but it may vary from person to person. On the contrary to the basal metabolic energy, the body produces additional metabolic energy during the activity period. From the next experimental data, the energy consumption during different activities carpen- 
tering, swimming and marathon (athletics) by a man of $65 \mathrm{~kg}$ weight consumed $16.7 \mathrm{~kJ} / \mathrm{min},(21-31.5) \mathrm{kJ} / \mathrm{min}$, and $31.5 \mathrm{~kJ} / \mathrm{min}$ energy respectively [13]. This data provides that the estimation value of the metabolic rate of carpentry person is $4198.08 \mathrm{w} / \mathrm{m}^{3}$ and the metabolic rate of the swimming person is $6598.79 \mathrm{w} / \mathrm{m}^{3}$. The scale of metabolic rate during various activities is shown in Table 1.

\subsection{Blood Perfusion}

Blood perfusion is the physiological term that refers to the process of delivery of arteries blood to a capillaries bed in the biological tissue. The arterioles and venous blood temperature may be different from the local tissue temperature. The rate of heat transfer between blood and local tissue is proportional to the product of a volumetric perfusion rate and the difference between the arterial blood temperature and the local tissue temperature [14]. This temperature may vary as a function of many transient and physiological and physical parameters. Pennes' mathematical model describes the effect of blood perfusion and metabolism on the energy balance within the tissue. These effects were incorporated into the standard thermal diffusion equation and modeled the bio-heat equation

$$
\rho c \frac{\partial T}{\partial t}=\nabla \cdot(K \nabla T)+\rho_{b} c_{b} w_{b}\left(T_{A}-T\right)+S(t)
$$

Several computer simulated methods are developed for the estimation of temperature distribution in the human body. Saxena et al. [15] used a variational finite element approach with linear shape function to find one dimensional unsteady temperature distribution in epidermis, dermis and subcutaneous tissues (SST) region assuming a rate of blood flow and rate of metabolic heat generation as a variable in the dermis part. Chao et al. [16] assumed two simple models and studied the temperature distribution curve in skin and subcutaneous tissue for certain paramaters values are constant. Agrawal [13] and Kenefick et al. [2] experimentally studied the amount of energy expenditure and blood flow rate during swimming and marathon. They estimated the maximum core temperature occurring $39.5^{\circ} \mathrm{C}$ in the human body during the exercise period. Acharya et al. [17] divided the dermal part into six skin layers and studied the metabolic effect in thermoregulation on human males and females. The authors suggested that skin temperature in males has more than females. Khanday and Saxena [18] assumed five layered skin in the human body and used one dimensional steady state model to the estimation of cold effect on the human dermal part. Saxena and Gupta [15] and Saxena and Arya [19] contributed the papers on the effect of

Table 1. Metabolic rate of different exercises.

\begin{tabular}{cc}
\hline Type of exercises & Metabolic rate $\left(\mathrm{w} / \mathrm{m}^{3}\right)$ \\
\hline Carpentering & 4198.08 \\
Swimming & 6598.79 \\
Marathon (running) & 7918.00 \\
\hline
\end{tabular}


blood flow and heat flow in human skin and subcutaneous tissue by using variational finite element method. Kumari and Adlakha [20] developed a numerical model to study the temperature distribution in human peripheral regions incorporated the blood mass flow rate, thermal conductivity and metabolic heat generation rate were constants during and after the exercise.

Gurung et al. [21] investigated the temperature distribution in three layers of a human dermal part in one dimensional unsteady state with quadratic shape function assuming that the outer skin is exposed to the atmosphere. Agrawal et al. [22] developed a model for the temperature distribution in a human limb by assuming an irregular tapered shaped limb with a variable radius and eccentricity. Khanday [23] explained the appearance of thermal stress on the human brain tissue in hypothermic conditions. Khanday and Sexana [18] studied the thermoregulation and fluid regulation in the human head and dermal region at cold environmental conditions by using variational finite element method. K.C. et al. [24] investigated the thermal effect of eyelid based on the properties of ambient temperature, evaporation rate, blood temperature and lens thermal conductivity in the human eye.

Previously, developed models have not studied on the temperature distribution in the human dermal part during the exercise. So this mathematical model has presented to estimate the metabolic energy produces differently in various exercises. The main objective of this study is to investigate the temperature profiles of epidermis, dermis and subcutaneous tissues during exercise. Since the body is an irregular geometry, the finite element method is appropriate to handle such an inhomogeneous discretized problem to get realistic values of temperature of different layers.

\section{Model for Metabolic Energy}

During physical exercise, metabolic rate increases due to an increase in the rate of blood flow. The continuous increases in blood flow are controlled by the mechanism of the body by rapidly producing metabolic energy at the beginning of the exercise and become constant after a certain time so it is plausible to consider the metabolic rate, increasing logistically in the form similar to the logistic curve. We consider the metabolic rate $S(t)$ equation based on exercise as

$$
S(t)=S_{0}+\frac{\boldsymbol{E}-S_{0}}{1+\mathrm{e}^{-\beta\left(t-t_{s i}\right)}}
$$

Figure 2 represents the unsteady behavior of metabolic rates of the normal human body during the various activities in 30 minutes period. The graph shows the threshold metabolic value during the marathon is $7918 \mathrm{w} / \mathrm{m}^{3}$, during swimming is $6598.79 \mathrm{w} / \mathrm{m}^{3}$ and during carpentering is $4198.08 \mathrm{w} / \mathrm{m}^{3}$ at $\beta=0.01 / \mathrm{s}$, and $t_{s i}=500 \mathrm{~s}$ with $B M R=1114 \mathrm{w} / \mathrm{m}^{3}$.

\section{Re-Model of Bioheat Equation}

Pennes' [14] and Perl [25] established the simplified bio-heat transfer model 


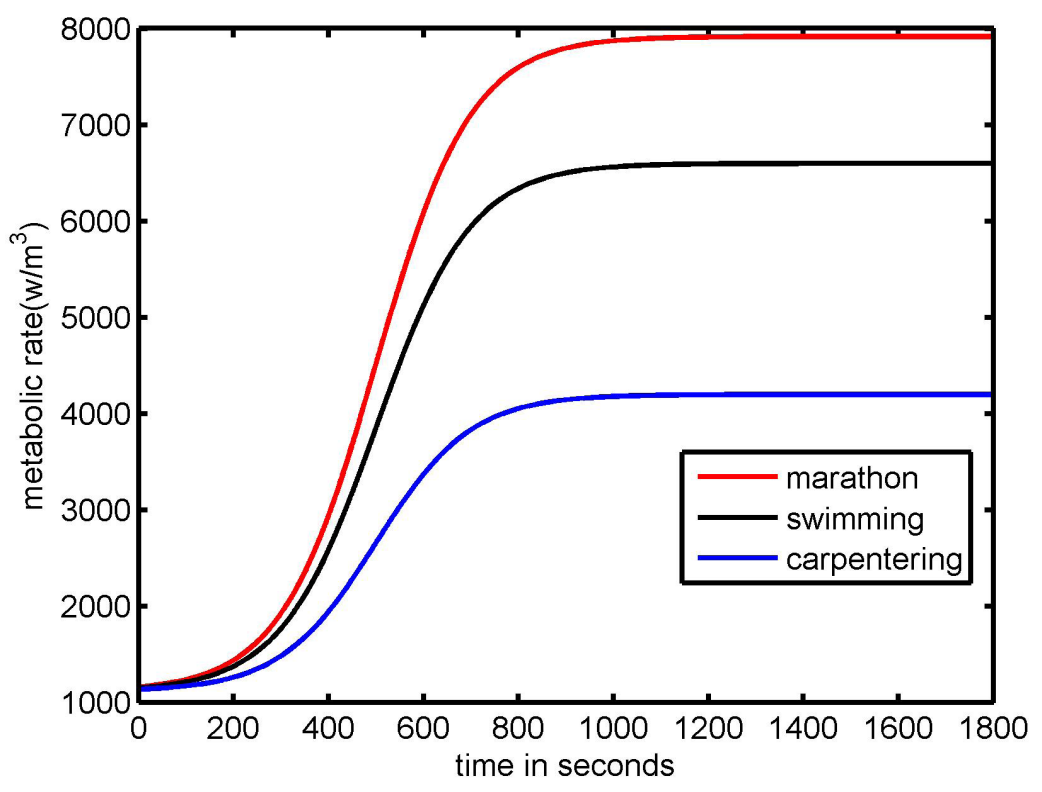

Figure 2. Metabolic rate behavior during different exercises.

equation to describe the effect of conduction, perfusion and metabolism. During the exercise period, additional heat energy arises and dissipated from the body to the environment by its mechanism. The resulting bio-heat equation with metabolic energy is re-formulated by

$$
\rho c \frac{\partial T}{\partial t}=\nabla \cdot(K \nabla T)+\rho_{b} c_{b} w_{b}\left(T_{A}-T\right)+\left(S_{0}+\frac{E-S_{0}}{1+\mathrm{e}^{-\beta\left(t-t_{s i}\right)}}\right)
$$

\section{Discretization of Domain}

Skin is the main organ that keeps helping the temperature balance in the human body. If any illness occurs in the body, the first symptom is changing body temperature [8]. In mathematical treatments of temperature distribution in the human dermal part, the skin layers can be regarded as a physical and physiological barrier with complex structures. The three natural layers of skin are epidermis, dermis and subcutaneous tissues (SST). The schematic diagram of the temperature distribution model in dermal parts of the human body is shown as in Figure 3.

Let $l_{1}, l_{2}-l_{1}$, and $l_{3}-l_{2}$ be the thickness of the layers of epidermis, dermis and subcutaneous tissue respectively. Let $T_{0}, T_{1}, T_{2}$ and $T_{3}$ be the respective nodal temperatures at a distance at $x=0, x=l_{1}, x=l_{2}$ and $x=l_{3}$ measured from the outer surface of the skin. $T^{(1)}, T^{(2)}$ and $T^{(3)}$ be the temperature function of epidermis, dermis and subcutaneous tissues respectively.

\section{Solution of the Model}

The governing equation that characterized the heat regulation in in-vivo tissue of human body during exercises is given by the partial differential Equation (1), which we can write for $1 \mathrm{D}$ as; 


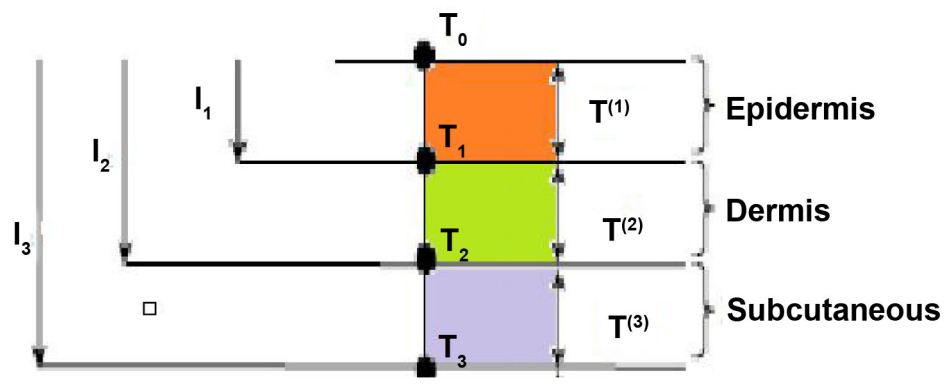

Figure 3. Schematic diagram of three layered skin.

$$
\rho c \frac{\partial T}{\partial t}=\frac{\partial}{\partial x}\left(k \frac{\partial T}{\partial x}\right)+M\left(T_{A}-T\right)+\left(S_{0}+\frac{E-S_{0}}{1+\mathrm{e}^{-\beta\left(t-t_{s i}\right)}}\right)
$$

where, $M=\rho_{b} c_{b} w_{b}\left(\mathrm{~J} / \mathrm{m}^{3} \cdot \mathrm{s} \cdot{ }^{\circ} \mathrm{C}\right)$

\section{Boundary Conditions}

1) Boundary condition at $x=0$ (skin surface)

The outer surface of the skin layer is exposed to the environment during the exercise period. Therefore heat flux is dissipated for $x=0$ and heat loss takes place from the outer surface due to conduction, convection, radiation and evaporation methods. So the net heat flux is calculated by mixed boundary,

$$
\left.K \frac{\partial T}{\partial x}\right|_{x=0}=h\left(T-T_{\infty}\right)+L E
$$

2) Boundary condition at $x=l_{3}$ (body core)

During Exercise, due to the rapid movement of muscle mass and an increase in heart rate, the body produces a large amount of metabolic heat energy and cannot dissipate all energy instantaneously at that time. The rate of heat loss does not offset the rate of heat gain so some heat energy stores in the body. That excess (stored) heat energy helps to increase the body core temperature up to $39^{\circ} \mathrm{C}$. So, the Dirichlet's inner boundary condition during exercise period is taken as

$$
T\left(l_{3}\right)=T_{b}=39^{\circ} \mathrm{C}
$$

Using Euler-Lagrange formula, the variational integral form of Equation (3) and Equation (4) is given by

$$
\begin{aligned}
I[T(x, t)]= & \frac{1}{2} \int_{\Omega}\left[K\left(\frac{\mathrm{d} T}{\mathrm{~d} x}\right)^{2}+M\left(T_{A}-T\right)^{2}-2 S(t) T+\rho c \frac{\mathrm{d} T^{2}}{\mathrm{~d} t}\right] \mathrm{d} x \\
& +\frac{1}{2} h\left(T_{0}-T_{\infty}\right)^{2}+L E T_{0} .
\end{aligned}
$$

In the model, the physical and physiological parameters depending on the layers of dermal part and are considered as given in Table 2.

Suppose, $I_{1}, I_{2}$ and $I_{3}$ are the integral solutions of three layers epidermis, dermis and subcutaneous tissue, respectively with $I=\sum_{i=1}^{n} I_{i}$. Solving the integrals $I_{1}, I_{2}$ and $I_{3}$ with parameters as considered in Table 2, we obtain $I_{1}$, $I_{2}$ and $I_{3}$ as functions of nodal values $T_{0}, T_{1}, T_{2}$, as given as below: 
Table 2. Assumption parameters in model.

\begin{tabular}{cccc}
\hline $\begin{array}{c}\text { Physical and } \\
\text { Physiological } \\
\text { parameters }\end{array}$ & $\begin{array}{c}\text { Epidermis } \\
l_{0} \leq x \leq l_{1}\end{array}$ & $\begin{array}{c}\text { Dermis } \\
l_{1} \leq x \leq l_{2}\end{array}$ & $\begin{array}{c}\text { Subcutaneous } \\
l_{2} \leq x \leq l_{3}\end{array}$ \\
\hline$K$ & $K_{1}$ & $K_{2}$ & $K_{3}$ \\
$M$ & $M_{1}=0$ & $M_{2}$ & $M_{3}$ \\
$T_{A}$ & $T_{A}^{(1)}=0$ & $T_{A}^{(2)}=T_{b}$ & $T_{A}^{(3)}=T_{b}$ \\
$S(t)$ & $S_{1}=0$ & $S_{2}=S_{0}+\frac{E-S_{0}}{1+\mathrm{e}^{-\beta\left(t-t_{0}\right)}}$ & $S_{3}=2\left[S_{0}+\frac{E-S_{0}}{1+\mathrm{e}^{-\beta\left(t-t_{0}\right)}}\right]$ \\
$T^{(i)}$ & $T^{(1)}=T_{0}+\left(\frac{T_{1}-T_{0}}{l_{1}}\right) x$ & $T^{(2)}=\frac{l_{2} T_{1}-l_{1} T_{2}}{l_{2}-l_{1}}+\left(\frac{T_{2}-T_{1}}{l_{2}-l_{1}}\right) x$ & $T^{(3)}=\frac{l_{3} T_{2}-l_{2} T_{3}}{l_{3}-l_{2}}+\left(\frac{T_{3}-T_{2}}{l_{3}-l_{2}}\right) x$ \\
\hline
\end{tabular}

$$
\begin{gathered}
I_{1}=A_{1}+B_{1} T_{0}+D_{1} T_{0}^{2}+E_{1} T_{1}^{2}+F_{1} T_{0} T_{1}+\alpha_{1} \frac{\mathrm{d}}{\mathrm{d} t}\left(T_{0}^{2}+T_{1}^{2}+T_{0} T_{1}\right) \\
I_{2}=A_{2}+B_{2} T_{1}+C_{2} T_{2}+D_{2} T_{1}^{2}+E_{2} T_{2}^{2}+F_{2} T_{1} T_{2}+\alpha_{2} \frac{\mathrm{d}}{\mathrm{d} t}\left(T_{1}^{2}+T_{2}^{2}+T_{1} T_{2}\right) \\
I_{3}=A_{3}+B_{3} T_{2}+C_{3} T_{3}+D_{3} T_{2}^{2}+E_{3} T_{3}^{2}+F_{3} T_{2} T_{3}+\alpha_{3} \frac{\mathrm{d}}{\mathrm{d} t}\left(T_{2}^{2}+T_{3}^{2}+T_{2} T_{3}\right) .
\end{gathered}
$$

where $A_{i}, B_{i}, D_{i}, E_{i}, F_{i}$ and $C_{j}$ with $1 \leq i \leq 3$ and $2 \leq j \leq 3$ are all constants whose values depend upon physical and physiological parameters of dermal part as given in Table 4. As a next step to finite element method, we differentiate $I_{1}, I_{2}$ and $I_{3}$ with respect to $T_{0}, T_{1}$ and $T_{2}$ and set $\frac{\mathrm{d} I}{\mathrm{~d} T_{i}}=0$, for $i=0,1,2$. On simplification, we obtain system of equations in matrix form

$$
P T+Q \dot{T}=R
$$

where,

$$
\begin{gathered}
P=\left(\begin{array}{ccc}
2 D_{1} & F_{1} & 0 \\
F_{1} & 2\left(D_{2}+E_{1}\right) & F_{2} \\
0 & F_{2} & 2\left(D_{3}+E_{2}\right)
\end{array}\right), Q=\left(\begin{array}{ccc}
2 \alpha_{1} & \alpha_{1} & 0 \\
\alpha_{1} & 2\left(\alpha_{1}+\alpha_{2}\right) & \alpha_{2} \\
0 & \alpha_{2} & 2\left(\alpha_{2}+\alpha_{3}\right)
\end{array}\right) \\
T=\left(\begin{array}{c}
T_{0} \\
T_{1} \\
T_{2}
\end{array}\right), \dot{\mathrm{d} T_{0}} \mathrm{~d}=\left(\begin{array}{c}
-B_{1} \\
\frac{\mathrm{d} T_{1}}{\mathrm{~d} t} \\
\frac{\mathrm{d} T_{2}}{\mathrm{~d} t}
\end{array}\right), R=\left(\begin{array}{c}
-B_{2} \\
-C_{2}-B_{3}-F_{3} T_{3}
\end{array}\right)
\end{gathered}
$$

\section{Numerical Results}

The threshold values of metabolic rate during physical activities: carpentering, swimming and marathon running are $4198.08 \mathrm{w} / \mathrm{m}^{3}, 6598.79 \mathrm{w} / \mathrm{m}^{3}$ and 7918 $\mathrm{w} / \mathrm{m}^{3}$ respectively. The values of physical and physiological parameters used for numerical simulation are taken as shown in Table 3 and Table 4.

In normal condition when the atmospheric temperature is below body core 
Table 3. The thickness of human skin layers in normal position [9].

\begin{tabular}{cccc}
\hline Skin layers & Epidermis layer & Dermis layer & Subcutaneous layer \\
\hline Thickness (metres) & 0.001 & 0.0035 & 0.005 \\
\hline
\end{tabular}

Table 4. Parameter values used in model [9] [21].

\begin{tabular}{ccc}
\hline Parameter & Value & Unit \\
\hline$L$ & $2,420,220$ & $\mathrm{~J} / \mathrm{kg}$ \\
$K_{1}$ & 0.209 & $\mathrm{w} / \mathrm{m} \cdot{ }^{\circ} \mathrm{C}$ \\
$K_{2}$ & 0.314 & $\mathrm{w} / \mathrm{m} \cdot{ }^{\circ} \mathrm{C}$ \\
$K_{3}$ & 0.418 & $\mathrm{w} / \mathrm{m} \cdot{ }^{\circ} \mathrm{C}$ \\
$h$ & 6.27 & $\mathrm{w} / \mathrm{m}^{2} \cdot{ }^{\circ} \mathrm{C}$ \\
$M_{2}$ & 1254 & $\mathrm{w} / \mathrm{m}^{3} \cdot{ }^{\circ} \mathrm{C}$ \\
$M_{3}$ & 1254 & $\mathrm{w} / \mathrm{m}^{3} \cdot{ }^{\circ} \mathrm{C}$ \\
$\rho_{1}$ & 1050 & $\mathrm{~kg} / \mathrm{m}^{3}$ \\
$\rho_{2}$ & 996 & $\mathrm{~kg} / \mathrm{m}^{3}$ \\
$\rho_{3}$ & 1050 & $\mathrm{~kg} / \mathrm{m}^{3}$ \\
$C_{1}$ & 3469.4 & $\mathrm{~J} / \mathrm{kg} \cdot{ }^{\circ} \mathrm{C}$ \\
$C_{2}$ & 1588.4 & $\mathrm{~J} / \mathrm{kg} \cdot{ }^{\circ} \mathrm{C}$ \\
$C_{3}$ & 1588.4 & $\mathrm{~J} / \mathrm{kg} \cdot{ }^{\circ} \mathrm{C}$ \\
\hline
\end{tabular}

temperature, the tissue temperature increases from the skin surface towards the body core temperature. So we consider the tissue temperature $T(x, 0)$ in linear order given by the equations

$$
T(x, 0)=T_{0}+\mu x
$$

At normal atmospheric temperature, initial skin temperature is considered $21^{\circ} \mathrm{C}$. The use of $\mu$ in Equation (8) is constant, whose numerical value is determined by taking the known value $T_{3}=T_{b}=39^{\circ} \mathrm{C}$ at $x=l_{3}$. We use the iterative method and the Crank-Nicolson method to solve the Equation (10). The Crank -Nicolson method gives

$$
\left(Q+\frac{\Delta t}{2} P\right) T^{(i+1)}=\left(Q-\frac{\Delta t}{2} P\right) T^{(i)}+\Delta t R
$$

Here, $\Delta t$ is the time interval and $T^{(0)}$ is the initial nodal temperature in $3 \times 1$ matrix form.

For the steady case of the model, we obtain the following matrix form of the system of algebraic equations

$$
P T=R
$$

\section{Steady State Results}

The results of the analysis for dermal layers temperature distribution during marathon, swimming and carpentering in steady state are presented through Figures 4 to 6 and Table 5 . 


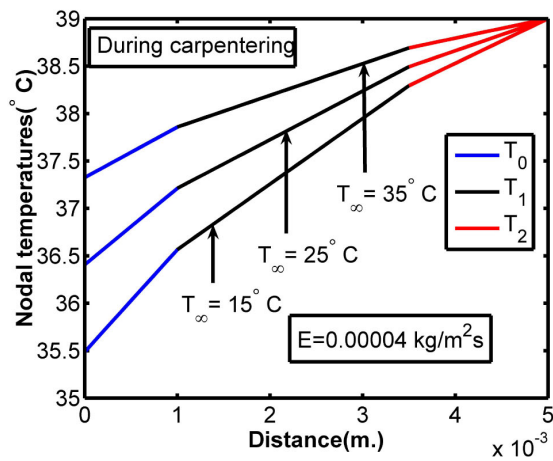

(a)

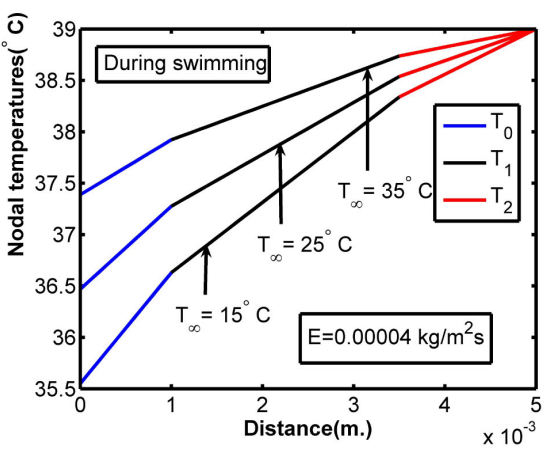

(b)

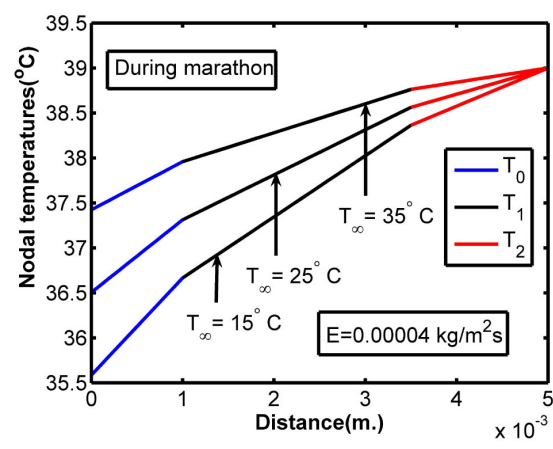

(c)

Figure 4. Estimation of epidermis, dermis and subcutaneous tissues temperature when $E=0.00004 \mathrm{~kg} / \mathrm{m}^{2} \cdot \mathrm{s}$ at ambient temperature $15^{\circ} \mathrm{C}, 25^{\circ} \mathrm{C}$ and $35^{\circ} \mathrm{C}$ during (a) carpentering, (b) swimming and (c) marathon.

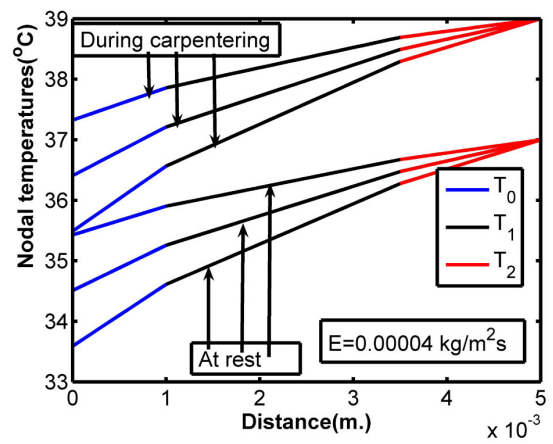

(a)

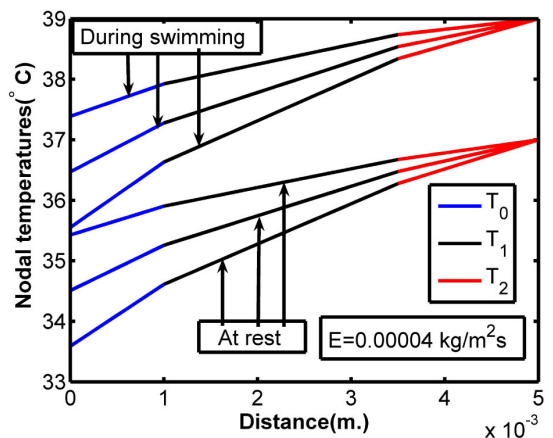

(b)

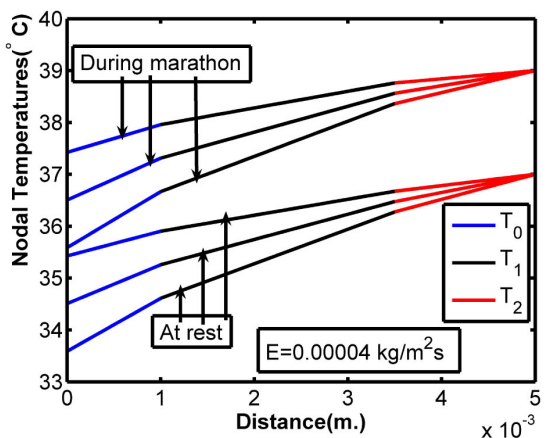

(c)

Figure 5. Estimation of epidermis, dermis and subcutaneous tissues temperature when $E=0.00004 \mathrm{~kg} / \mathrm{m}^{2} \cdot \mathrm{s}$ at ambient temperature $15^{\circ} \mathrm{C}, 25^{\circ} \mathrm{C}$ and $35^{\circ} \mathrm{C}$ (a) during carpentering and rest, (b) during swimming and rest (c) during marathon and rest.

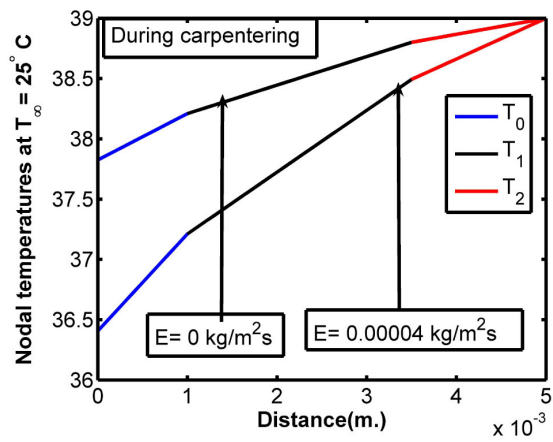

(a)

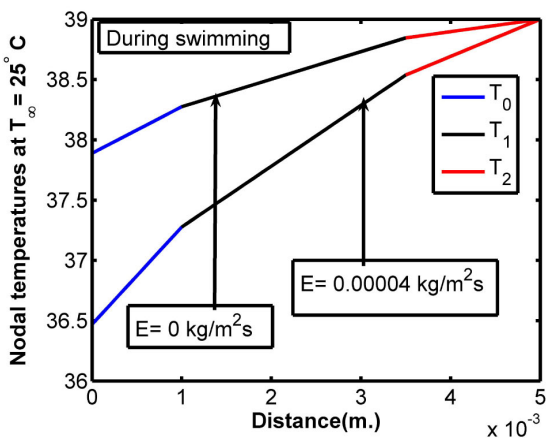

(b)

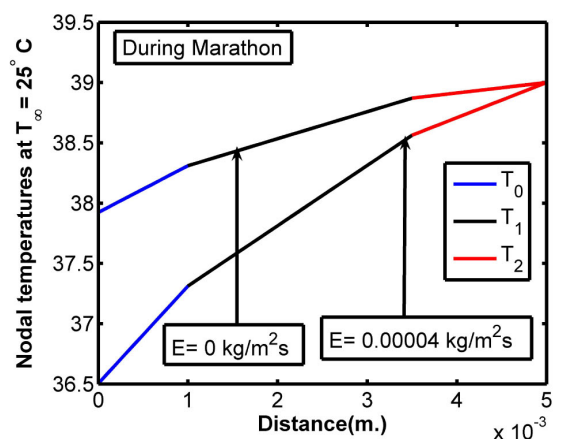

(c)

Figure 6. Estimation of epidermis, dermis and subcutaneous tissues temperature when $E=0 \mathrm{~kg} / \mathrm{m}^{2} \cdot \mathrm{s}$ and $E=0.00004 \mathrm{~kg} / \mathrm{m}^{2} \cdot \mathrm{s}$ at ambient temperature $25^{\circ} \mathrm{C}$ during (a) carpentering (b) swimming and (c) marathon.

From the graph in Figure 4 it is observed that there are significant variations in temperature distribution in the layers of skin due to change in atmospheric temperature in carpentering, swimming and marathon. But no significant changes in temperature distribution are observed during these activities at a given atmospheric temperature. 
Table 5. Steady state temperature of three layered skin during carpentering, swimming, marathon and rest position at $E=0.00004 \mathrm{~kg} / \mathrm{m}^{2} \cdot \mathrm{s}$.

\begin{tabular}{ccccc}
\hline Position & $\begin{array}{c}\text { Ambient } \\
\text { temp. }\left({ }^{\circ} \mathrm{C}\right)\end{array}$ & $\begin{array}{c}\text { Epidermis layered } \\
\text { temp. }\left({ }^{\circ} \mathrm{C}\right)\end{array}$ & $\begin{array}{c}\text { Dermis layered } \\
\text { temp. }\left({ }^{\circ} \mathrm{C}\right)\end{array}$ & $\begin{array}{c}\text { subcutaneous layered } \\
\text { temp. }\left({ }^{\circ} \mathrm{C}\right)\end{array}$ \\
\hline At rest & 15 & 33.58 & 34.61 & 36.27 \\
During carpentering & 15 & 35.48 & 36.56 & 38.29 \\
During swimming & 15 & 35.54 & 36.63 & 38.33 \\
During marathon & 15 & 35.58 & 36.66 & 38.36 \\
At rest & 25 & 34.50 & 35.26 & 36.47 \\
During carpentering & 25 & 36.40 & 37.21 & 38.49 \\
During swimming & 25 & 36.46 & 37.28 & 38.53 \\
During marathon & 25 & 36.50 & 37.31 & 38.56 \\
At rest & 35 & 35.42 & 35.90 & 36.67 \\
During carpentering & 35 & 37.32 & 37.85 & 38.69 \\
During swimming & 35 & 37.38 & 37.92 & 38.73 \\
During marathon & 35 & 37.42 & 37.95 & 38.76 \\
\hline
\end{tabular}

From the graph in Figure 5(a), it is observed that the epidermis layer has more temperature by $1.90^{\circ} \mathrm{C}$, the dermis layer has more temperature by $1.95^{\circ} \mathrm{C}$ and subcutaneous tissue has more temperature by $2.02^{\circ} \mathrm{C}$ at $E=0.00004 \mathrm{~kg} / \mathrm{m}^{2} \cdot \mathrm{s}$ and at each ambient temperature $T_{\infty}=15^{\circ} \mathrm{C}, 25^{\circ} \mathrm{C}$ and $35^{\circ} \mathrm{C}$ during carpentering than rest position.

From the graph in Figure 5(b), the result shows that the epidermis layer has more temperature by $1.96^{\circ} \mathrm{C}$, the dermis layer has more temperature by $2.02^{\circ} \mathrm{C}$ and subcutaneous tissue has more temperature by $2.06^{\circ} \mathrm{C}$ at $E=0.00004 \mathrm{~kg} / \mathrm{m}^{2} \cdot \mathrm{s}$ and at each ambient temperature $T_{\infty}=15^{\circ} \mathrm{C}, 25^{\circ} \mathrm{C}$ and $35^{\circ} \mathrm{C}$ during swimming than rest position.

From the graph in Figure 5(c), it is observed that the epidermis layer has more temperature by $2.00^{\circ} \mathrm{C}$, the dermis layer has more temperature by $2.05^{\circ} \mathrm{C}$ and subcutaneous tissue has more temperature by $2.09^{\circ} \mathrm{C}$ at $E=0.00004 \mathrm{~kg} / \mathrm{m}^{2} \cdot \mathrm{s}$ and at each ambient temperature $T_{\infty}=15^{\circ} \mathrm{C}, 25^{\circ} \mathrm{C}$ and $35^{\circ} \mathrm{C}$ during marathon than rest position.

From the graph in Figures 6(a)-(c), it is observed that each skin layer has more temperature at $E=0 \mathrm{~kg} / \mathrm{m}^{2} \cdot \mathrm{s}$ than at $E=0.00004 \mathrm{~kg} / \mathrm{m}^{2} \cdot \mathrm{s}$ at fixed environment temperature $25^{\circ} \mathrm{C}$ in carpentering, swimming and marathon. This shows that temperature of dermal layer control by producing the essential sweat from the body when the environment temperature is high during the activities.

In the present Table 5, the table shows the steady state temperature of three skin layered during different activities at various ambient temperatures. The temperature of each dermal layer during the marathon is more than swimming and carpentering at each ambient temperature $15^{\circ} \mathrm{C}, 25^{\circ} \mathrm{C}$, and $35^{\circ} \mathrm{C}$. The temperature of each dermal layer during swimming is more than carpentering due 
to different metabolic rates at the same ambient temperature.

\section{Unsteady State Results}

The graphs of unsteady steady case for atmospheric temperatures, $T_{\infty}=15^{\circ} \mathrm{C}$, $25^{\circ} \mathrm{C}$ and $35^{\circ} \mathrm{C}$ are presented in Figures 7 to 9 and it's numerical results are shown in Table 6 and Table 7.

Figure 7 represents the tissue temperatures during the different activities at

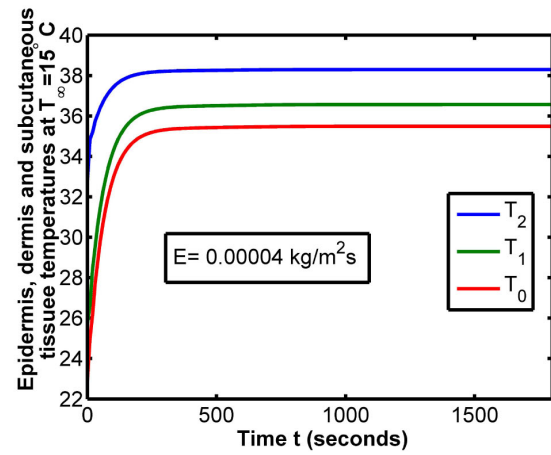

(a)

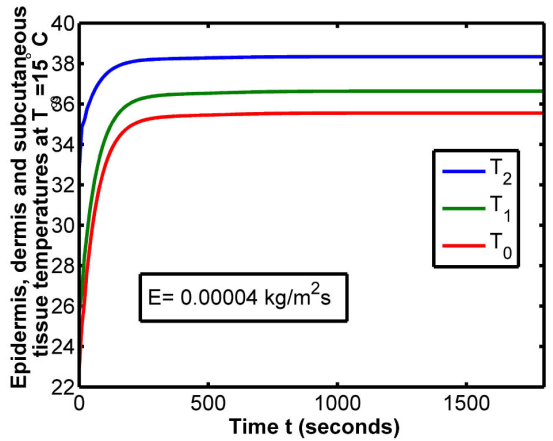

(b)

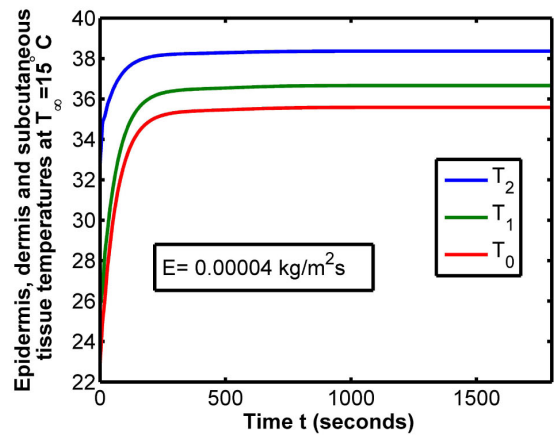

(c)

Figure 7. Estimation of the epidermis, dermis and subcutaneous tissue temperatures at $T_{\infty}=15^{\circ} \mathrm{C}$ and $E=0.00004 \mathrm{~kg} / \mathrm{m}^{2} \cdot \mathrm{s}$ during (a) carpentering, (b) swimming and (c) marathon.

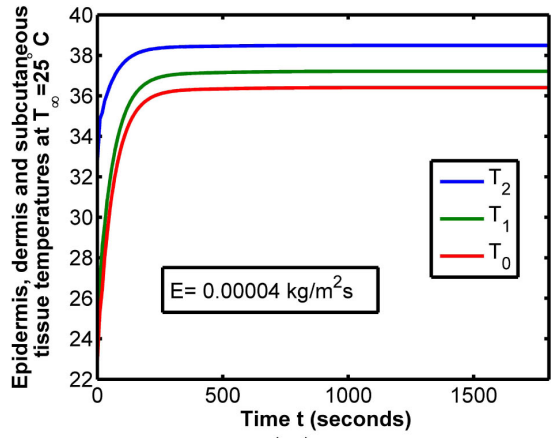

(a)

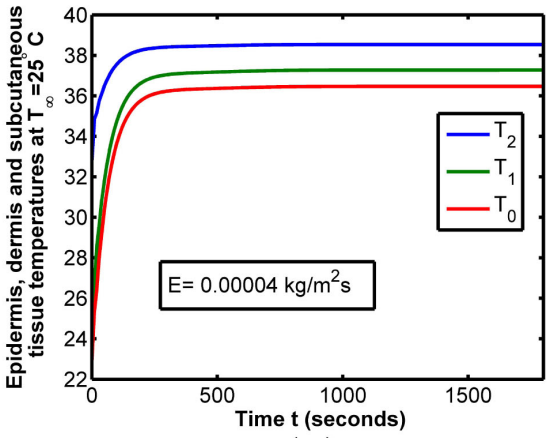

(b)

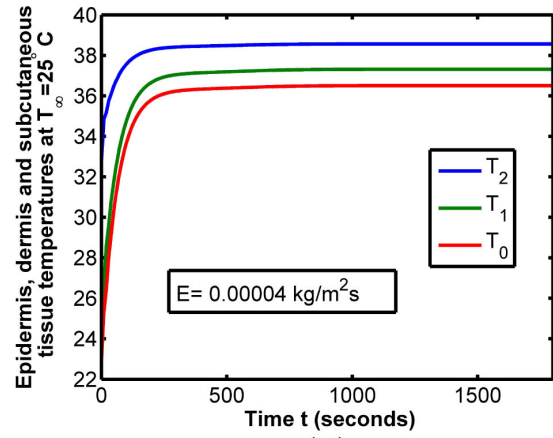

(c)

Figure 8. Observation of the epidermis, dermis and subcutaneous tissue temperatures at $E=0.00004 \mathrm{~kg} / \mathrm{m}^{2} \cdot \mathrm{s}$ and $T_{\infty}=25^{\circ} \mathrm{C}$ during (a) carpentering, (b) swimming and (c) marathon.

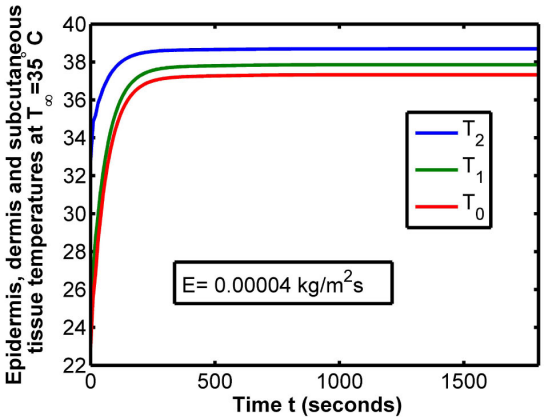

(a)

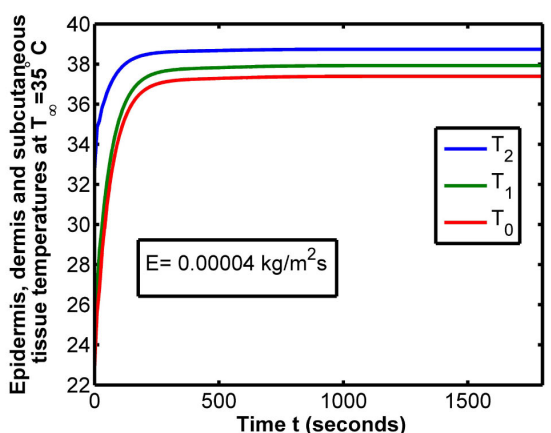

(b)

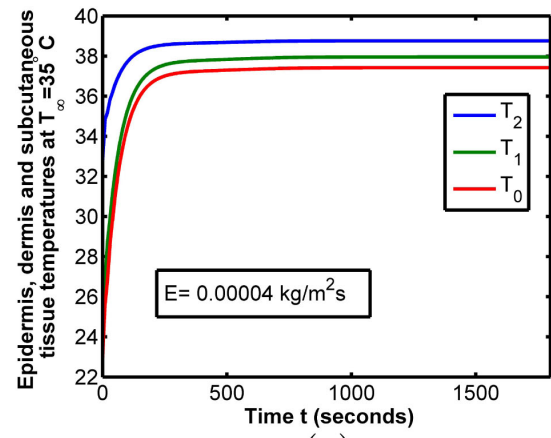

(c)

Figure 9. Estimation of epidermis, dermis and the subcutaneous tissue temperatures at $E=0.00004 \mathrm{~kg} / \mathrm{m}^{2} \cdot \mathrm{s} \quad T_{\infty}=35^{\circ} \mathrm{C}$ during (a) carpentering, (b) swimming and (c) marathon. 
$T_{\infty}=15^{\circ} \mathrm{C}$. The results show the temperatures in the epidermis layer increased to $35.48^{\circ} \mathrm{C}, 35.54^{\circ} \mathrm{C}$ and $35.58^{\circ} \mathrm{C}$, temperatures in the dermis layer increased to $36.56^{\circ} \mathrm{C}, 36.63^{\circ} \mathrm{C}$ and $36.66^{\circ} \mathrm{C}$ and temperatures in the subcutaneous tissue increased to $38.29^{\circ} \mathrm{C}, 38.33^{\circ} \mathrm{C}$ and $38.36^{\circ} \mathrm{C}$ at $E=0.00004 \mathrm{~kg} / \mathrm{m}^{2} \cdot \mathrm{s}$ during carpentering, swimming and marathon respectively.

On observing Figure 8, at $T_{\infty}=25^{\circ} \mathrm{C}$ and $E=0.00004 \mathrm{~kg} / \mathrm{m}^{2} \cdot \mathrm{s}$, the subcutaneous tissue temperature is greater by $3.20^{\circ} \mathrm{C}$ than epidermis layer and is greater by $1.97^{\circ} \mathrm{C}$ than dermis layer temperatures during carpentering. The subcutaneous tissue temperature is greater by $3.18^{\circ} \mathrm{C}$ than the epidermis and is greater by $1.96^{\circ} \mathrm{C}$ than dermis layer temperatures during swimming. During the marathon, the subcutaneous tissue temperature is greater by $3.17^{\circ} \mathrm{C}$ than the epidermis and is greater by $1.94^{\circ} \mathrm{C}$ than dermis layer temperatures. These results exhibit that subcutaneous tissue temperature is higher than dermis and epidermis layers because subcutaneous tissue is nearer from the body core with constant body core temperature.

Figure 9 reveals the temperatures variation between the dermis and subcutaneous tissue is higher than the temperatures variations between the epidermis and dermis layers at $T_{\infty}=35^{\circ} \mathrm{C}$ and $E=0.00004 \mathrm{~kg} / \mathrm{m}^{2} \cdot \mathrm{s}$ during carpentering, swimming and marathon.

In present Table 6 , the maximum temperatures of epidermis, dermis and subcutaneous tissue respectively are raised to $37.42^{\circ} \mathrm{C}, 37.95^{\circ} \mathrm{C}$ and $38.76^{\circ} \mathrm{C}$ during the marathon, $37.38^{\circ} \mathrm{C}, 37.92^{\circ} \mathrm{C}$ and $38.73^{\circ} \mathrm{C}$ during swimming and $37.32^{\circ} \mathrm{C}, 37.85^{\circ} \mathrm{C}$ and $38.69^{\circ} \mathrm{C}$ during carpentering at ambient temperature $35^{\circ} \mathrm{C}$ and $E=0.00004 \mathrm{~kg} / \mathrm{m}^{2} \cdot \mathrm{s}$. These results execute that the temperature of each skin layer increases due to the rise in the metabolic rate during the exercises. Table 7 represents the temperatures of epidermis, dermis, and subcutaneous tissue during different physical activities at different ambient temperatures and $E=0.00008 \mathrm{~kg} / \mathrm{m}^{2} \cdot \mathrm{s}$. The table shows the maximum temperatures of epidermis, dermis, and subcutaneous tissue respectively increase to $36.00^{\circ} \mathrm{C}, 36.96^{\circ} \mathrm{C}$ and $38.45^{\circ} \mathrm{C}$ during marathon, increase to $35.96^{\circ} \mathrm{C}, 36.92^{\circ} \mathrm{C}$, and $38.42^{\circ} \mathrm{C}$, during swimming and increase to $35.90^{\circ} \mathrm{C}, 36.85^{\circ} \mathrm{C}$, and $38.38^{\circ} \mathrm{C}$ during carpentering at ambient temperature $35^{\circ}$.

On comparing Table 6 and Table 7, the results exhibit that the temperature of the skin layers fall due to loss of more heat energy in the form of sweat at high sweat rate.

Table 6. Estimation of the unsteady state skin layers temperature at $E=0.00004 \mathrm{~kg} / \mathrm{m}^{2} \cdot \mathrm{s}$ during carpentering, swimming and marathon.

\begin{tabular}{cccccccccc}
\hline $\begin{array}{c}\text { Ambient } \\
\text { temperature }\end{array}$ & \multicolumn{2}{c}{$\begin{array}{c}\text { Temperature during } \\
\text { carpentering }\end{array}$} & \multicolumn{3}{c}{$\begin{array}{c}\text { Temperature during } \\
\text { swimming }\end{array}$} & \multicolumn{4}{c}{$\begin{array}{c}\text { Temperature during } \\
\text { marathon }\end{array}$} \\
\hline$\left(T_{\infty}\right)$ & $T_{0}$ & $T_{1}$ & $T_{2}$ & $T_{0}$ & $T_{1}$ & $T_{2}$ & $T_{0}$ & $T_{1}$ & $T_{2}$ \\
\hline $15^{\circ} \mathrm{C}$ & 35.48 & 36.56 & 38.29 & 35.54 & 36.63 & 38.33 & 35.58 & 36.66 & 38.36 \\
$25^{\circ} \mathrm{C}$ & 36.40 & 37.21 & 38.49 & 36.46 & 37.28 & 38.53 & 36.50 & 37.31 & 38.56 \\
$35^{\circ} \mathrm{C}$ & 37.32 & 37.85 & 38.69 & 37.38 & 37.92 & 38.73 & 37.42 & 37.95 & 38.76 \\
\hline
\end{tabular}


Table 7. Estimation of the unsteady state skin layers temperature at $E=0.00008 \mathrm{~kg} / \mathrm{m}^{2} \cdot \mathrm{s}$ during carpentering, swimming and marathon.

\begin{tabular}{cccccccccc}
\hline $\begin{array}{c}\text { Ambient } \\
\text { temperature }\end{array}$ & \multicolumn{2}{c}{$\begin{array}{c}\text { Temperature during } \\
\text { carpentering }\end{array}$} & \multicolumn{3}{c}{$\begin{array}{c}\text { Temperature during } \\
\text { swimming }\end{array}$} & \multicolumn{4}{c}{$\begin{array}{c}\text { Temperature during } \\
\text { marathon }\end{array}$} \\
\hline$\left(T_{\infty}\right)$ & $T_{0}$ & $T_{1}$ & $T_{2}$ & $T_{0}$ & $T_{1}$ & $T_{2}$ & $T_{0}$ & $T_{1}$ & $T_{2}$ \\
\hline $15^{\circ} \mathrm{C}$ & 34.06 & 35.56 & 37.98 & 34.13 & 35.63 & 38.03 & 34.16 & 35.66 & 38.05 \\
$25^{\circ} \mathrm{C}$ & 34.98 & 36.21 & 38.18 & 35.05 & 36.27 & 38.23 & 35.08 & 36.31 & 38.25 \\
$35^{\circ} \mathrm{C}$ & 35.90 & 36.85 & 38.38 & 35.96 & 36.92 & 38.42 & 36.00 & 36.96 & 38.45 \\
\hline
\end{tabular}

\section{Discussion and Conclusion}

The metabolic rate increases due to increases of the oxygen consumption by the body during physical activities. It helps to increase the temperature of the body. When the environment temperature increases, the metabolic rate in the body decreases. In the human body, the normal core temperature is $37^{\circ} \mathrm{C}$ so, on or above $37^{\circ} \mathrm{C}$, the body produces negligible metabolic heat [17]. In this model, the ambient temperatures $15^{\circ} \mathrm{C}, 25^{\circ} \mathrm{C}$ and $35^{\circ} \mathrm{C}$ are taken.

More active physical activity produces more sweat due to the fast movement of muscle mass. The analysis also shows, carpentering produces less metabolic energy than swimming and swimming produces less metabolic energy than the marathon. In this model sweat release rates on the exercises are taken as 0.00004 $\mathrm{kg} / \mathrm{m}^{2} \mathrm{~s}$ and $0.00008 \mathrm{~kg} / \mathrm{m}^{2} \mathrm{~s}$.

Figures 7-9 exhibit that the temperatures of epidermis, dermis and subcutaneous tissue increase rapidly at the beginning and reach to the steady temperatures after a certain period. These figures also reveal that the subcutaneous tissue temperatures reach earlier to steady temperatures than epidermis and dermis temperatures. This is due to increase of the metabolic rate on increasing the lean muscle mass and lose adipose fat tissue in subcutaneous tissue during activities. These results also demonstrate that the steady-state temperature of each dermal layer is achieved more during the marathon than swimming and carpentering due to more metabolic rate during the marathon. The unsteady and steady both results execute that the environment temperature gives significant changes in temperature in human dermal part.

The above result suggests that the temperature of each node increases by decreasing the sweat evaporation rate and vice versa at the same ambient temperature. This shows that the sweat evaporation rate is the catalyst in the thermoregulation process. All of the previous researchers developed models have not determined the temperature distribution in human dermal part by the computational method during the activity period. So this model is developed for the temperature distribution in dermal parts of human body during activities. The thermal effect of physical activities is quite significant. It also uses to develop models regarding physical work for labourers, military, other sports persons, etc. based on their physical and physiological characters. 


\section{Conflicts of Interest}

The authors declare no conflicts of interest regarding the publication of this paper.

\section{References}

[1] Alexiou, S. (2014) The Effect of Water Temperature on the Human Body and the Swimming Effort. Biology of Exercise, 10, 9-26.

[2] Kenefick, R.W., Cheuvront, S.N. and Sawka, M.N. (2007) Thermo-Regulatory Function during the Marathon. Sports Medicine, 37, 312-315. https://doi.org/10.2165/00007256-200737040-00010

[3] Fernandes, A., et al. (2014) Measuring Skin Temperature before, during and after Exercise, a Comparison of Thermocouple and Infrared Thermography. Physiological Measurement, 35, 189-203. https://doi.org/10.1088/0967-3334/35/2/189

[4] Mayers, G.E. (1981) Alcohol's Effect of Body Temperature, Hyporthermia, Hyperthermia and Poikilothermia. Brain Research Bulletin, 7, 209-220. https://doi.org/10.1016/0361-9230(81)90085-X

[5] Acharya, S., Gurung, D.B. and Saxena, V.P. (2013) Effect of Metabolic Reaction on Thermo-Regulation in Human Male and Female Body. Applied Mathematics, 4, 39-48. https://doi.org/10.4236/am.2013.45A005

[6] Kimberly Holland, K. (2016) Thermoregulation, Healthline. University of Illinois, College of Medicine, Champaign.

[7] Tansey, E.A. and Johnson, C.D. (2015) Recent Advances in Thermoregulation. Advances in Physiology Education, 39, 139-148. https://doi.org/10.1152/advan.00126.2014

[8] Gurung, D.B. and Shrestha, D.C. (2016) Mathematical Study of Temperature Distribution in Human Dermal Part during Physical Exercises. Journal of the Institute of Engineering, 12, 63-76. https://doi.org/10.3126/jie.v12i1.16727

[9] Gurung, D.B. (2007) Mathematical Study of Abnormal Thermo-Regulation in Human Dermal Part. Ph.D. Thesis, Kathmandu University, Dhulikhel.

[10] Sawka, M.N., et al. (1993) Nutritional Needs in Hot Environments. The National Academics of Sciences, Engineering and Medicine, National Academy Press, Washington DC, Ch. 1, 3-44.

[11] Diaz, M.D. and Becker, D.E. (2010) Physiological and Clinical Considerations during Sedation and General Anesthesia, American Dental Society of Anesthesiology. Anesthesia Progress, 57, 25-33. https://doi.org/10.2344/0003-3006-57.1.25

[12] Durnin, J.V.G.A. (1992) Energy Metabolism in the Elderly. In: Nutrition of the Elderly, Nutrition Workshop Series, Vol. 29, Raven, New York, 51-63.

[13] Agrawal, D.C. (1999) Work and Heat Energy Expenditure during Swimming. Physical Education, 34, 220-226. https://doi.org/10.1088/0031-9120/34/4/309

[14] Pennes, H.H. (1948) Analysis of Tissue and Arterial Blood Temperature in Resting Human Forearm. Journal of Applied Physiology, 1, 93-122. https://doi.org/10.1152/jappl.1948.1.2.93

[15] Saxena, V.P. and Gupta, M.P. (1994) Variational Finite Element Method Heat Flow Problems in Human Limbs. International Journal of Mathematics and Mathematical Sciences, 17, 771-778. https://doi.org/10.1155/S0161171294001079

[16] Chao, K.N., Eisley, J.G. and Yang, W.J. (1973) Heat and Water Migration in Regional Skins and Subcutaneous Tissue. Proc. Bio. Mech. Symp. (ASME), 69-72. 
[17] Acharya, S., Gurung, D.B. and Saxena, V.P. (2015) Two Dimensional Finite Element Method for Metabolic Effect in Thermoregulation on Human Males and Females Skin Layers. Journal of Coastal Life Medicine, 3, 623-629. https://doi.org/10.12980/JCLM.3.2015J5-38

[18] Khanday, M.A. and Saxena, V.P. (2009) Finite Element Approach for the Study of Thermoregulation in Human Head Exposed to Cold Environment. AIP Conference Proceedings, 1146, 375-385. https://doi.org/10.1063/1.3183555

[19] Saxena, V.P. and Arya, D. (1988) Unsteady State Heat Flow in Epidermis and Dermis of a Human Body. Indian Academy of Sciences (Math. Sci.), 98, 71-80. https://doi.org/10.1007/BF02880973

[20] Kumari, B. and Adlaka, N. (2013) One Dimensional Finite Difference Model to Study Temperature Distribution in Peripheral Regions of a Human Body during and after Exercise. Journal of Medical Imaging and Health Informatics, 3, 179-186. https://doi.org/10.1166/jmihi.2013.1153

[21] Gurung, D.B., Saxena, V.P. and Adhikari, P.R. (2009) FEM Approach to One Dimensional Unsteady State Temperature Distribution in Human Dermal Parts with Quadratic Shape Function. Journal of Applied Mathematics and Informatics, 27, 301-331.

[22] Agrawal, M., Pardarsani, K.R. and Adlaka, N. (2014) State Temperature Distribution in Dermal Regions of an Irregular Tapered Shaped Human Limb with Variable Eccentricity. Journal of Thermal Biology, 44, 27-34. https://doi.org/10.1016/j.jtherbio.2014.06.004

[23] Khanday, M.A. (2013) Theoretical Approach to Study the Thermal Stress on the Human Brain Tissue in Hypothermic Conditions. International Journal of Advanced Computer and Mathematical Sciences, 4, 181-187.

[24] Gurung, D.B., Adhikari, P.R., et al. (2014) Thermal Effect of the Eyelid in Human Eye Temperature Model. Journal of Applied Mathematics and Informatics, 32, 649-663. https://doi.org/10.14317/jami.2014.649

[25] Perl, W. (1962) Heat and Matter Distribution in Body Tissues and the Determination of Tissue Blood Flow by Local Clearance Method. Journal of Theoretical Biology, 2, 201-235. https://doi.org/10.1016/0022-5193(62)90025-5 


\section{Nomenclature}

\begin{tabular}{|c|c|}
\hline$H$ & Metabolic heat produced during exercise \\
\hline$W$ & Heat amount used to perform external work \\
\hline$R$ & Heat radiation \\
\hline$C$ & Conductive and convective heat \\
\hline$E$ & Evaporative heat loss \\
\hline$H$ & Heat storage \\
\hline$c$ & Tissue specific heat capacity \\
\hline$K$ & Tissue thermal conductivity \\
\hline$S(t)$ & Metabolic rate during exercise \\
\hline$L$ & Latent heat capacity \\
\hline$h$ & Combined heat transfer coefficient due to convection and radiation \\
\hline$K_{1}$ & Thermal conductivity of the epidermis layer \\
\hline$K_{2}$ & Thermal conductivity of the dermis layer \\
\hline$K_{3}$ & Thermal conductivity of the subcutaneous tissue \\
\hline$c_{1}$ & Specific heat capacity of epidermis layer \\
\hline$c_{2}$ & Specific heat capacity of dermis layer \\
\hline$C_{3}$ & Specific heat capacity of subcutaneous tissue \\
\hline$l_{1}$ & Thickness of epidermis layer \\
\hline$l_{2}$ & Thickness of epidermis and dermis layers \\
\hline$l_{3}$ & Total thickness of skin and subcutaneous tissue \\
\hline$M_{1}$ & Blood mass flow in epidermis layer \\
\hline$M_{2}$ & Blood mass flow in dermis layer \\
\hline$M_{3}$ & Blood mass flow in subcutaneous tissue \\
\hline$S_{1}$ & Metabolic rate in epidermis layer \\
\hline$S_{2}$ & Metabolic rate in dermis layer \\
\hline$S_{3}$ & Metabolic rate in subcutaneous tissue \\
\hline$w_{b}$ & Blood perfusion rate \\
\hline$c_{b}$ & Blood specific heat capacity \\
\hline$\rho$ & Tissue density \\
\hline$\rho_{b}$ & Blood density \\
\hline$\rho_{1}$ & Density of epidermis layer \\
\hline$\rho_{2}$ & Density of dermis layer \\
\hline$\rho_{3}$ & Density of subcutaneous tissue \\
\hline$\Omega$ & Domain of layered skin \\
\hline$\beta$ & Exercise controlled parameter \\
\hline $\mathrm{T}$ & Tissue temperature \\
\hline$T_{A}$ & Arterial blood temperature \\
\hline$T_{\infty}$ & Ambient temperature \\
\hline$T_{b}$ & Body core temperature \\
\hline$S_{0}$ & Basal metabolic rate \\
\hline $\mathrm{E}$ & Exercise threshold metabolism \\
\hline $\mathrm{t}$ & Exercise time period \\
\hline$t_{s i}$ & Sigmoid's mid point of the curve over the time for extensive exercise \\
\hline
\end{tabular}

